\title{
DOUTORADO EM ENFERMAGEM
}

Há um ano, a Câmara de Pós-Graduação autorizou a implantação de um Programa de Pós-Graduação em Enfermagem - nível de doutorado - a ser desenvolvido, conjuntamente, por duas unidades da Universidade de São Paulo: Escola de Enfermagem e Escola de Enfermagem de Ribeirão Preto.

Esta autorização encerrou a tramitação de processos que vinha sendo efetuada desde, aproximadamente, 1977. Nos últimos meses de 1980 e primeiros de 1981 foi exigido, da comissão encarregada de preparar a estruturação do Programa, um sem número de viagens, reuniões e trabalhos individuais e em grupo para que fossem atendidas todas as solicitações da Câmara de Pós-Graduação.

O grupo encarregado de implantar o Programa conseguiu realizar a primeira seleção de candidatas em outubro de 1981.

Em março de 1982 foi iniciado o curso e, apesar das dificuldades inerentes a todo começar, acrescidas da distância entre as duas Escolas, o grupo de trabalho pode afirmar que está implantado o primeiro Doutorado em Enfermagem do Brasil.

A importância deste, para a Enfermagem Brasileira é indiscutivel. Seu efeito sobre o exercício da profissão, provavelmente, será sentido quando as enfermeiras com Doutorado em Enfermagem começarem a pesquisar Enfermagem e a ater-se ao ensino de Enfermagem no Programa de Graduação.

Apesar da Enfermagem ser uma profissão que aplica conhecimentos de várias áreas do saber, no meu entender, uma coisa é estudar princípios de ciências básicas que podem, de alguma forma, influenciar o cuidado de Enfermagem, outra é estabelecer princípios de enfermagem que sirvam de base para o desenvolvimento desse cuidado.

Tenho esperança de que a enfermeira venha competir no mercado de trabalho tendo como arma, não a força legal do diploma ou a de uma classe politicamente poderosa, mas, única e simplesmente, a competência profissional. Esta esperança só poderá se transformar em fato quando os professores de enfermagem começarem a ensinar os seus alunos a resolver os problemas de enfermagem com soluções encontradas no estudo e no exercício da própria profissão. 